\section{Screening Spinach Cultivars for White Rust Resistance and Bolting}

\author{
Smiljana Goreta ${ }^{1}$ and Daniel I. Leskovar ${ }^{2,3}$
}

AdDitional INDEx words. Albugo occidentalis, Spinacia oleracea, leaf area infected

\begin{abstract}
SumMARY. Areas with mild climate conditions are suitable for growing winter spinach (Spinacia olevacea L.). Successful production depends on choosing slowbolting cultivars resistant to major diseases in each area. Field experiments with a total of 18 cultivars were conducted during 8 years in the Winter Garden region of Texas, an area known for its high white rust (Albugo occidentalis G.W. Wils) inoculum. Spinach cultivars differed widely in their resistance to both white rust and bolting, and the incidence of both traits was more severe as the season progressed. White rust infection increased linearly with average monthly minimal air temperature. Cultivars Fidalgo, Springfield, and Springer were slow bolting and are suitable for areas with no white rust incidence, while cvs. ASR-318, DMC 66-09, Fall Green, Samish, and San Juan were more white rust resistant.
\end{abstract}

S pinach is a cool season crop cultivated in areas with an average temperature range from 60 to 65 ${ }^{\circ} \mathrm{F}$. Young plants can withstand freezing temperatures as low as $15^{\circ} \mathrm{F}$ without sustaining severe injury (Yamaguchi, 1983). Since winters are mild in the Winter Garden area of southern Texas (geographic area west of San Antonio), spinach is a crop with great economic impact. It is cultivated in about 7300 acres in southwestern Texas (Texas Agricultural Statistics Service, 2003) and contributes to about $29.4 \%$ of the total U.S. processed spinach market, with a $\$ 41.5$ million economic impact (Pena, 2004). Spinach is also a good source of vitamin $\mathrm{C}$, minerals, and a major source of carotenoids in the American diet (Magee, 1997).

Spinach is a long-day plant, but bolting rate increases if cold exposure of growing plants is followed by higher temperatures and long days (Yamaguchi, 1983). Bolting is not enhanced if seed is exposed to low temperatures

${ }^{1}$ Institute for Adriatic Crops, Put duilova 11, Split 21000, Croatia.

${ }^{2}$ Texas Agricultural Experiment Station, Vegetable \& Fruit Improvement Center, Texas A\&M University, 1619 Garner Field Rd., Uvalde, TX 78801.

The authors thank K. Kolenda and D. Moore for their valuable technical help. The senior author acknowledges financial support from the Fulbright Program. Appreciation is also extended to seed companies for providing seeds. Partial funding was also provided by CSREES-USDA under Agreement No. 2005-3440216401, "Designing Foods for Health." Mention of a trademark, proprietary product or vendor does not constitute a guarantee or warranty of the product, nor does it imply approval or disapproval to the exclusion of other products or vendors that may also be suitable.

${ }^{3}$ Professor, corresponding author; e-mail address: d-leskovar@tamu.edu during development on the mother plant (Wiebe, 1989), but sensitivity to photoperiod is present as early as in the transplant stage (Kim et al., 2000). Although it has been shown that bolting can be delayed by the manipulation of light during transplant production (Chun et al., 2000), this practice is not feasible for large-scale production. Resistance to bolting among different cultivars has been known for a long time (Webb and Thomas, 1976), and therefore bolting-resistant cultivars have been developed (Brandenberger et al., 2004).

Breeding techniques have also been used extensively to develop spinach cultivars resistant to white rust infection (Goode et al., 1987). White rust is one of the major spinach foliar fungal diseases in southern Texas due to favorable winter conditions for disease development. Relatively warm days and low humidity affect desiccation of conidia, while the moisture condensation and cool temperatures at night favor germination and host penetration (Raabe and Pound, 1952). Optimal temperatures for disease development range from 54 to $64^{\circ} \mathrm{F}$, and leaf wetness enhances disease development (Sullivan et al., 2002). Initial symptoms of infection are small chlorotic lesions on the leaf surface (Correll et al., 1994). As the disease develops it can cause leaf yellowing, stunted growth, and finally a significant economic loss for the spinach crop (Leskovar and Kolenda, 2002). Crop management strategies such as fungicide application and amount of irrigation can have significant impacts on the development and control of this disease (Leskovar and Black, 1994).

Growing cultivars resistant to white rust can contribute to an overall better quality product, while preserving the environment by decreasing pesticide inputs. During the last 20 years the Texas A\&M University, Texas Agricultural Experiment Station in Uvalde, has been a unique site for screening cultivars with resistance to white rust due to its high level of inoculum. The objective of this study was to determine spinach cultivars tolerant to white rust and bolting in order to make recommendations for commercial production. Both experimental and commercial cultivars of spinach produced for fresh market and processing were included in this 8 -year study.

\section{Material and methods}

Cultivars AND METEOROLOGICAL DATA. From 1997 to 2004 , a total of 18 spinach cultivars were tested at the Texas Agricultural Experiment Station in Uvalde $\left(29^{\circ} 1^{\prime} \mathrm{N}, 99^{\circ} 5^{\prime} \mathrm{W}\right)$ (Table $\left.\mathrm{l}\right)$. 'DMC 66-07', 'DMC 66-09', 'DMC 66-01', and 'Samish' were continually tested during eight growing seasons whereas other cultivars were tested at least during three seasons (Tables 3, 4, and 5). Cultivars of all leaf types were included in the study with prevailing semi/savoy (seven cultivars) and flat (eight cultivars) leaves.

The spinach nursery was established in the period from 24 Oct. to 19 Dec., depending on the season, with the aim to include planting dates most common for winter production in southern Texas (Table 1). Basic meteorological data are presented for the growing period from November until

\begin{tabular}{llll}
\hline $\begin{array}{l}\text { Units } \\
\text { To convert U.S. to SI, } \\
\text { multiply by }\end{array}$ & U.S. unit & SI unit & $\begin{array}{l}\text { To convert SI to U.S., } \\
\text { multiply by }\end{array}$ \\
\hline 0.4047 & acre $(\mathrm{s})$ & $\mathrm{ha}$ & $2.471 \mathrm{l}$ \\
0.3048 & $\mathrm{ft}$ & $\mathrm{m}$ & 3.2808 \\
2.5400 & inch $(\mathrm{es})$ & $\mathrm{cm}$ & 0.3937 \\
25.4000 & inch $(\mathrm{es})$ & $\mathrm{mm}$ & 0.0394 \\
1.1209 & $\mathrm{lb} / \mathrm{acre}$ & $\mathrm{kg} \cdot \mathrm{ha}^{-1}$ & 0.8922 \\
$\left({ }^{\circ} \mathrm{F}-32\right) \div 1.8$ & ${ }^{\circ} \mathrm{F}$ & ${ }^{\circ} \mathrm{C}$ & $\left(1.8 \times{ }^{\circ} \mathrm{C}\right)+32$
\end{tabular}


March in each season (Table 2). The average monthly minimal air temperatures were the lowest in December and January each season except in 2001-02, where the coldest month was February. Rainfall ranged from 2.6 inches in the season 1999-2000 up to 13.5 inches in 1997-98, with the most rainfall events in November of four seasons. Minimum relative humidity was under $50 \%$ except in 1998-99 (53.6\%) and 2000-01 (64.2\%).

Cultural practices. The spinach nursery was established on a silty clay loam (fine-silty, mixed, hyperthermic Aridic Calciustoll) soil. Seeds were planted with a precision planter on the same field in each season.

Individual plots consisted of four lines per bed with two lines on each side of the bed. Spacing was 9 inches between the two center-lines and 4 inches between the two side-lines. Seeds along the lines were spaced at $2 \frac{1}{2}$ inches. Beds were 40 inches apart (center to center) with 25 -ft-long plots. Herbicide $S$-metolachlor at $1.1 \mathrm{lb} /$ acre a.i. (Dual II Magnum; Syngenta Crop Protection, Greensboro, N.C.) was sprayed over the surface at planting and incorporated with $20 \mathrm{~mm}$ of sprinkler irrigation each year. A preplant fertilizer of $50 \mathrm{lb} /$ acre nitrogen $(\mathrm{N}), 20 \mathrm{lb} /$ acre phosphorus, and $0.2 \mathrm{lb} /$ acre zinc was broadcasted. Additional $\mathrm{N}$ fertilization from 50 to $70 \mathrm{lb} /$ acre was applied as needed on each season. Irrigation was provided by furrow systems according to crop requirement based on weather data.

There was no attempt to control white rust or other diseases in the nursery. To facilitate infection and achieve uniform disease distribution throughout the nursery, each cultivar was planted adjacent to a row with a genotype known to be highly susceptible to white rust from results of previous studies. In addition, sprinkler irrigation was applied at frequent intervals for 15 to $30 \mathrm{~min}$ during late afternoons, to purposely enhance leaf wetness for white rust development.

WHITE RUST AND BOLTING EVALUATION. Leaf area infected with white rust was evaluated at least once in each season between January and March, and twice in seasons 1997-98, 1998-99, 1999-2000, and 2001-02 (Table 1). At each sampling period a total of 24 mature leaves from the two center rows of each plot were collected, with a total of 96 leaves per cultivar.

Table 1. Planting dates, number of tested cultivars, and evaluation dates for white rust incidence and percentage of bolting for spinach cultivars in southern Texas for 1998-2005 seasons.

\begin{tabular}{|c|c|c|c|c|c|}
\hline \multirow[b]{3}{*}{ Season } & \multirow{3}{*}{$\begin{array}{c}\text { Planting } \\
\text { date }\end{array}$} & \multirow{3}{*}{$\begin{array}{c}\text { Tested } \\
\text { cultivars } \\
\text { (no.) }\end{array}$} & \multicolumn{3}{|c|}{ Evaluation dates } \\
\hline & & & \multicolumn{2}{|c|}{ White rust } & \multirow[b]{2}{*}{ Bolting } \\
\hline & & & lst & 2nd & \\
\hline 1997-98 & 4 Nov. & 11 & 27 Jan. & 10 Feb. & 17 Feb. \\
\hline 1998-99 & 9 Dec. & 12 & 23 Feb. & 9 Mar. & 25 Mar. \\
\hline 1999-2000 & 7 Dec. & 15 & 1 Mar. & 14 Mar. & 1 Mar. \\
\hline 2000-01 & 19 Dec. & 11 & 3 Mar. & --- & 9 Apr. \\
\hline $2001-02$ & 24 Oct. & 14 & 9 Jan. & 29 Jan. & 3 Mar. \\
\hline $2002-03$ & 23 Nov. & 11 & 18 Mar. & --- & --- \\
\hline $2003-04$ & 25 Nov. & 7 & 26 Mar. & --- & 26 Mar. \\
\hline $2004-05$ & 1 Dec. & 5 & 31 Mar. & --- & 21 Mar. \\
\hline
\end{tabular}

Table 2. Average monthly air temperature, total rainfall, number of rainfall events, and relative humidity for spinach grown in southern Texas, 1997-2005.

\begin{tabular}{|c|c|c|c|c|c|c|c|c|c|}
\hline \multirow[b]{2}{*}{ Month } & \multicolumn{9}{|c|}{ Year } \\
\hline & 1997 & 1998 & 1999 & 2000 & 2001 & 2002 & 2003 & 2004 & 2005 \\
\hline \multicolumn{10}{|c|}{ Maximum air temp $\left({ }^{\circ} F\right)^{z}$} \\
\hline January & --- & 67 & 67 & 69 & 60 & 67 & 62 & 63 & 65 \\
\hline February & --- & 67 & 73 & 75 & 68 & 66 & 64 & 65 & 63 \\
\hline March & --- & 71 & 74 & 80 & 67 & 75 & 74 & 76 & 73 \\
\hline November & 62 & 71 & 77 & 65 & 73 & 69 & 72 & 71 & --- \\
\hline December & 70 & 63 & 67 & 57 & 64 & 65 & 68 & 66 & --- \\
\hline \multicolumn{10}{|c|}{ Minimum air temp $\left({ }^{\circ} F\right)$} \\
\hline January & --- & 49 & 39 & 43 & 40 & 43 & 39 & 45 & 46 \\
\hline February & --- & 47 & 46 & 51 & 48 & 39 & 43 & 42 & 49 \\
\hline March & --- & 52 & 53 & 56 & 47 & 50 & 50 & 55 & 49 \\
\hline November & 46 & 55 & 49 & 48 & 54 & 46 & 51 & 50 & --- \\
\hline December & 41 & 43 & 40 & 37 & 43 & 41 & 40 & 39 & --- \\
\hline \multicolumn{10}{|c|}{ Rainfall (inches) } \\
\hline January & --- & 4.6 & 0.0 & 0.2 & 1.7 & 0.2 & 0.8 & 1.0 & 1.6 \\
\hline February & --- & 3.1 & 0.0 & 2.1 & 0.6 & 0.1 & 0.7 & 1.5 & 2.9 \\
\hline March & --- & 2.6 & 3.2 & 0.2 & 1.6 & 1.2 & 0.5 & 3.2 & 1.9 \\
\hline November & 1.0 & 2.4 & 0.0 & 3.9 & 2.0 & 0.9 & 2.1 & 5.3 & --- \\
\hline December & 2.2 & 0.6 & 0.1 & 0.8 & 1.5 & 0.4 & 0.2 & 0.1 & --- \\
\hline \multicolumn{10}{|c|}{ Rainfall events (no.) } \\
\hline January & --- & 3 & 0 & 2 & 9 & 3 & 7 & 10 & 2 \\
\hline February & --- & 7 & 0 & 3 & 10 & 3 & 10 & 8 & 13 \\
\hline March & --- & 6 & 7 & 3 & 10 & 4 & 8 & 9 & 6 \\
\hline November & 5 & 9 & 0 & 13 & 8 & 6 & 10 & 9 & --- \\
\hline December & 1 & 2 & 3 & 8 & 8 & 6 & 1 & 2 & --- \\
\hline \multicolumn{10}{|c|}{ Minimum relative humidity (\%) } \\
\hline January & --- & 54 & 44 & 44 & 62 & 47 & 58 & 53 & 48 \\
\hline February & --- & 43 & 39 & 48 & 65 & 31 & 64 & 44 & 56 \\
\hline March & --- & 42 & 52 & 46 & 62 & 44 & 45 & 52 & 39 \\
\hline November & 53 & 71 & 42 & 70 & 60 & 52 & 52 & 53 & --- \\
\hline December & 36 & 62 & 37 & 62 & 59 & 55 & 30 & 36 & --- \\
\hline
\end{tabular}

${ }^{\mathrm{z}}\left({ }^{\circ} \mathrm{F}-32\right) / 1.8={ }^{\circ} \mathrm{C}$.

y 1 inch $=2.54 \mathrm{~cm}$.

Samples from each plot were taken in four areas, each at approximate row cross-sections with leaf positions of $0^{\circ}, 45^{\circ}$, and $90^{\circ}$ angles (left row); $90^{\circ}$, $45^{\circ}$, and $0^{\circ}$ angles (right row). Each leaf was classified into one of six classes: $0 \%, 1 \%, 5 \%, 10 \%, 20 \%$, and $50 \%$ leaf area infected, depending on leaf area with white rust lesions (Dainello et al.,
1990). Percentage of leaves infected with white rust was evaluated in each season except for 1997-98 and 199899. Each leaf with at least one visible lesion was assumed as infected.

Bolting rate was estimated for all seasons except 2002-03, from $17 \mathrm{Feb}$. (1997-98) until 9 Apr. (2000-01) for all tested cultivars (Table 1). Bolting 
rate was estimated as percentage of plants bolted per replication: $0=$ none; $1=1 \%$ to $20 \% ; 2=21 \%$ to $40 \% ; 3=$ $41 \%$ to $60 \% ; 4=61 \%$ to $80 \% ; 5=81 \%$ to $100 \%$.

Data analysis. The experiments were set up as a randomized completeblock design with four replications per cultivar. Homogeneity and normality of variance were tested and data were transformed when necessary. Analysis of variance (ANOVA) was carried out for each year separately using proc GLM of the SAS software package (SAS Institute, 1989). After significant Ftest, means separation was performed with the least significant difference test. Linear regression analysis was performed between meteorological data and white rust and bolting incidence. If the evaluation was done within the first $15 \mathrm{~d}$ of the month, then data from the preceding month were used as an independent variable in the regression analysis. As an example, in 1997-98 season, evaluation of white rust was done on 27 Jan. and 10 Feb., and for both data sets meteorological data for Jan. 1998 were used as the independent variable. Bolting evaluation on 17 Feb. was correlated with meteorological data for Feb. 1998. The same approach was applied for other seasons.

\section{Results and discussion}

LEAF AREA INFECTED. Leaf area infected with white rust in all cultivars ranged from an average $2.2 \%$ for the first evaluation in 2001-02 up to $50.2 \%$ in the $2003-04$ season (Table $3)$. As expected, when evaluations were conducted twice in the same year, leaf area infected with white rust generally was higher on the second evaluation, except in the season 1997-98 for 'Cascade', 'DMC 66-07', 'DMC 6609', 'Fall Green', and 'Vancouver'. In the 1999-2000 season, an increase in leaf area infected from $5.1 \%$ (as overall cultivars average) on 1 Mar., to $44.7 \%$ measured on 14 Mar. is evidence that the disease progress can be very fast once infection is present under favorable weather conditions. During Feb. and Mar. 2000 the average monthly maximal and minimal air temperatures were higher than in other years (Table 2 ), which probably contributed to the fast disease spreading. Average leaf area infected below 10\% was noticed only for 'ASR-318' (three season-average), while less than $15 \%$ of infected leaf area was found for 'DMC 66-09' (eight seasons), 'Fall Green' (three seasons), 'Samish' (eight seasons), 'San Juan' (three seasons) and 'Unipack 277' (three seasons) (Table 3). A high level of white rust infection was recorded for 'Cascade' (the most sensitive cultivar), but also for 'Springfield', 'Springer', 'ASR-157', and 'ACX 3665' in all years tested.

LeAves INFeCTED. This sensitive evaluation (only one lesion determines leafinfection) showed disease progression during the season. The lowest percentage of leaves infected with white rust in all cultivars (overall average $17.8 \%$ ) occurred on 9 Jan. 2002 with a more than 3 -fold increase by the second evaluation on 29 Jan. 2002 (Table 4). Similarly, for other growing seasons, percentage of leaves infected with white rust was always greater in the second evaluation. When 'DMC 66-09', 'DMC 66-16', 'Samish', 'Unipack 277', and 'ASR-318' were tested together within a season, there were no significant differences among them, all showing fewer infected leaves (Table 4). Greater numbers of infected leaves were noted for 'Cascade', followed by 'ACX 3665' and 'Springfield'.

Bolting. All spinach cultivars grown throughout the winter readily bolted as days grew longer and temperatures increased, both conditions known as favorable for generative development (Chun et al., 2000). With all cultivars, more than $40 \%$ (bolting rate $\geq 3$ ) of plants bolted in 1998-99,

Table 3. Leaf area infected with white rust of spinach cultivars in seasons 1998-2005 in southern Texas.

\begin{tabular}{|c|c|c|c|c|c|c|c|c|c|c|c|c|c|c|c|}
\hline \multirow[b]{3}{*}{ Cultivar } & \multirow[b]{3}{*}{ Source ${ }^{\mathrm{z}}$} & \multirow[b]{3}{*}{$\begin{array}{l}\text { Leaf } \\
\text { type }\end{array}$} & \multicolumn{12}{|c|}{ Season and date of evaluation } & \multirow[b]{3}{*}{$\begin{array}{c}\text { Cultivar } \\
\text { avg }\end{array}$} \\
\hline & & & \multicolumn{2}{|c|}{ 1997-98 } & \multicolumn{2}{|c|}{ 1998-99 } & \multicolumn{2}{|c|}{ 1999-2000 } & \multirow{2}{*}{$\begin{array}{c}\frac{2000-01}{3} \\
\text { Mar. }\end{array}$} & \multicolumn{2}{|c|}{ 2001-02 } & \multirow{2}{*}{$\begin{array}{c}\frac{2002-03}{18} \\
\text { Mar. }\end{array}$} & \multirow{2}{*}{$\begin{array}{c}2003-04 \\
26 \\
\text { Mar. }\end{array}$} & \multirow{2}{*}{$\begin{array}{c}2004-05 \\
31 \\
\text { Mar. }\end{array}$} & \\
\hline & & & $\begin{array}{c}27 \\
\text { Jan. }\end{array}$ & $\begin{array}{c}10 \\
\text { Feb. }\end{array}$ & $\begin{array}{c}23 \\
\text { Feb. }\end{array}$ & $\begin{array}{c}9 \\
\text { Mar. }\end{array}$ & $\begin{array}{c}1 \\
\text { Mar. }\end{array}$ & $\begin{array}{c}14 \\
\text { Mar. }\end{array}$ & & $\begin{array}{c}9 \\
\text { Jan. }\end{array}$ & $\begin{array}{c}29 \\
\text { Jan. }\end{array}$ & & & & \\
\hline Bolero & Petoseed & Flat & $166^{y}$ & 190 & & & $9 \mathrm{l}$ & 447 & 346 & 8 & 280 & 216 & 470 & & 257 \\
\hline Cascade & Chriseed & Flat & 33.5 & 24.4 & 24.7 & 42.6 & 16.3 & 56.7 & & 5.9 & 55.8 & $\begin{array}{l}21.0 \\
53.9\end{array}$ & $4 / .0$ & & 34.9 \\
\hline DMC 66-07 & Del Monte & Flat & 20.8 & 14.3 & 8.7 & 16.0 & 5.0 & 36.9 & 24.0 & 2.1 & 13.3 & 28.9 & 63.2 & 12.8 & 20.5 \\
\hline DMC 66-16 & Del Monte & Flat & 11.4 & 14.0 & 4.2 & 6.0 & 3.1 & 35.5 & 17.1 & 0.5 & 18.3 & 30.9 & 40.6 & 8.4 & 15.8 \\
\hline Fall Green & Chriseed & Savoy & 11.3 & 8.6 & 4.7 & 13.2 & 3.3 & 44.4 & & 1.4 & 17.3 & & & & 13.0 \\
\hline F-380 & Chriseed & Semi/Savoy & 17.0 & 19.0 & 5.6 & 12.1 & 1.3 & 45.3 & & 0.0 & 19.3 & 36.5 & & & 17.3 \\
\hline Fidalgo & Asgrow & Semi/Savoy & 10.6 & 15.2 & 5.0 & 12.4 & 3.4 & 50.3 & & & & & & & 16.2 \\
\hline Samish & Chriseed & Savoy & 8.3 & 11.8 & 5.6 & 6.5 & 3.0 & 37.5 & 13.5 & 0.8 & 10.1 & 27.6 & 40.7 & 7.5 & 14.4 \\
\hline San Juan & Asgrow & Savoy & 4.0 & 10.3 & 4.9 & 10.4 & 2.9 & 43.9 & & & & & & & 12.7 \\
\hline Vancouver & Asgrow & Semi/Savoy & 21.7 & 20.8 & 12.5 & 20.1 & 7.1 & 45.9 & & & & & & & 21.4 \\
\hline ASR-157 & Asgrow & Flat & & & & & & & 23.7 & 3.8 & 23.9 & 25.8 & 59.1 & 15.9 & 25.4 \\
\hline ASR-318 & Asgrow & Semi/Savoy & & & & & & & 12.0 & 0.0 & 2.8 & 18.5 & & & 8.3 \\
\hline \multirow[t]{3}{*}{ ACX 3665} & Chriseed & Flat & & & & & & & & 2.7 & 33.6 & 48.8 & 63.6 & & 37.2 \\
\hline & & Season avg & 15.1 & 15.0 & 8.1 & 15.6 & 5.1 & 44.7 & 22.4 & 2.2 & 22.8 & 32.8 & 50.2 & 11.1 & \\
\hline & & $\operatorname{LSD}_{(0.05)}$ & 8.9 & 9.5 & 7.2 & 9.2 & 5.3 & 9.8 & 9.8 & 4.9 & 10.5 & 16.3 & 15.3 & 6.9 & \\
\hline
\end{tabular}

${ }^{\mathrm{z}}$ Asgrow = Asgrow brand, Seminis Vegetable Seeds, Oxnard, Calif.; Bejo = Bejo Seeds, Oceano, Calif.; Chriseed = Chriseed brand, Alf Christianson Seed Co., Mount Vernon, Wash.; Del Monte = Del Monte Corp., San Francisco; Petoseed = Petoseed brand, Seminis Vegetable Seeds; Royal Sluis = Royal Sluis brand, Seminis Vegetable Seeds.

y Each value represents an average of four replications for a total of 96 leaves classified as $0 \%, 1 \%, 5 \%, 10 \%, 20 \%$, and $50 \%$ of leaf area with white rust lesions. 
Table 4. Leaves infected with white rust of spinach cultivars in seasons 1998-2005 in southern Texas.

\begin{tabular}{|c|c|c|c|c|c|c|c|c|c|c|c|}
\hline \multirow[b]{3}{*}{ Cultivar } & \multirow[b]{3}{*}{ Source ${ }^{\mathrm{z}}$} & \multirow{3}{*}{$\begin{array}{c}\text { Leaf } \\
\text { type }\end{array}$} & \multicolumn{8}{|c|}{ Season and date of evaluation } & \multirow{3}{*}{$\begin{array}{c}\text { Cultivar } \\
\text { avg }\end{array}$} \\
\hline & & & \multicolumn{2}{|c|}{$1999-2000$} & \multirow{2}{*}{$\frac{2000-01}{3 \text { Mar. }}$} & \multicolumn{2}{|c|}{ 2001-02 } & \multirow{2}{*}{$\frac{2002-03}{18 \mathrm{Mar} .}$} & \multirow{2}{*}{$\frac{2003-04}{26 \text { Mar. }}$} & \multirow{2}{*}{$\frac{2004-05}{31 \text { Mar. }}$} & \\
\hline & & & 1 Mar. & 14 Mar. & & 9 Jan. & 29 Jan. & & & & \\
\hline Bolero & Petoseed & Flat & $65.6^{x}$ & 93.8 & 86.1 & 16.7 & 72.9 & 71.1 & 97.7 & & 72.0 \\
\hline Cascade & Chriseed & Flat & 89.6 & 96.8 & & 34.4 & 93.8 & 91.3 & & & 81.2 \\
\hline DMC 66-07 & Del Monte & Flat & 46.9 & 89.6 & 81.3 & 13.5 & 57.6 & 87.8 & 98.3 & 78.8 & 69.2 \\
\hline DMC 66-09 & Del Monte & Flat & 21.1 & 83.0 & 66.7 & 8.8 & 65.6 & 77.9 & 96.2 & 78.6 & 62.2 \\
\hline DMC 66-16 & Del Monte & Flat & 29.8 & 89.6 & 67.7 & 6.3 & 62.9 & 72.1 & 96.0 & 80.5 & 63.1 \\
\hline Fall Green & Chriseed & Savoy & 47.9 & 87.5 & & 16.4 & 61.5 & & & & 53.3 \\
\hline F-380 & Chriseed & Semi/Savoy & 28.1 & 88.5 & & 24.0 & 71.9 & 86.8 & & & 59.9 \\
\hline Fidalgo & Asgrow & Semi/Savoy & 35.0 & 94.8 & & & & & & & 64.9 \\
\hline Samish & Chriseed & Savoy & 39.6 & 85.5 & 55.2 & 8.3 & 52.1 & 76.4 & 97.9 & 66.5 & 60.2 \\
\hline San Juan & Asgrow & Savoy & 43.2 & 90.6 & & & & & & & 66.9 \\
\hline Vancouver & Asgrow & Semi/Savoy & 59.7 & 91.3 & & & & & & & 75.5 \\
\hline RS 950579 & Royal Sluis & Semi/Savoy & 41.1 & 86.5 & 70.0 & & & & & & 65.9 \\
\hline Springfield & Bejo & Flat & 59.4 & 96.8 & 87.5 & 38.3 & 95.8 & & & & 75.6 \\
\hline Springer & Bejo & Semi/Savoy & 58.3 & 95.8 & 85.5 & 33.0 & 67.3 & 83.2 & & & 70.5 \\
\hline Unipack 277 & Royal Sluis & Semi/Savoy & 28.1 & 89.4 & 58.8 & 3.1 & 43.3 & & & & 44.5 \\
\hline ASR-157 & Asgrow & Flat & & & 74.2 & 21.6 & 76.2 & 85.4 & 97.0 & 81.4 & 72.6 \\
\hline ASR-318 & Asgrow & Semi/Savoy & & & 68.6 & 1.0 & 21.9 & 69.2 & & & 40.2 \\
\hline \multirow[t]{3}{*}{ ACX 3665} & Chriseed & Flat & & & & 23.7 & 92.7 & 87.4 & 100.0 & & 76.0 \\
\hline & & Season avg & 46.2 & 90.6 & 72.9 & 17.8 & 66.8 & 80.8 & 97.6 & 77.2 & \\
\hline & & $\operatorname{LSD}_{(0.05)}$ & 20.1 & 9.2 & 12.8 & 16.4 & 13.6 & 14.6 & 3.8 & 11.9 & \\
\hline
\end{tabular}

${ }^{2}$ Asgrow = Asgrow brand, Seminis Vegetable Seeds, Oxnard, Calif.; Bejo = Bejo Seeds, Oceano, Calif.; Chriseed = Chriseed brand, Alf Christianson Seed Co., Mount Vernon, Wash.; Del Monte = Del Monte Corp., San Francisco; Petoseed = Petoseed brand, Seminis Vegetable Seeds; Royal Sluis = Royal Sluis brand, Seminis Vegetable Seeds. Leaf with at least one visible lesion was assumed as infected.

${ }^{x}$ Each value represents an average of four replications.

2000-01, 2003-04, and 2004-05 seasons after 15 Mar. (Table 1 and $5)$, indicating that commercial field harvesting should be finished earlier than mid-March to obtain high quality spinach. Low bolting rate was found for 'Fidalgo' (1.0 to 1.6), 'Springfield' (none to 1.5), and 'Springer' (none to $2.0)$. Bolting rate for 'Samish' ranged from 4.5 to 5.0 during all 8 years of testing. Greater bolting rates were also found for 'DMC 66-07', 'DMC 66-09', 'DMC 66-16', and 'ASR-157' (Table 5), and therefore these cultivars are considered susceptible to bolting after overwintering in the field. Spinach fields with only $10 \%$ of bolting plants are considered unacceptable for harvest (Brandenberger et al., 2004). If bolting-susceptible cultivars are planted in December, generally one harvest (cut) would be obtained, in contrast to two or three cuts if planting occurs earlier (October). Since the scope of this study was to test plants under highly favorable conditions for bolting, we expect these results could be applicable to areas with mild climatic conditions where spinach is also grown as an overwintering crop.

Due to considerable variation of white rust infection and bolting rate over all years, meteorological data (Table 2) were linearly regressed with the incidence of white rust infection (leaf area infected and leaves infected) and bolting rate (Tables 3 , 4 , and 5). There was no relationship among average monthly maximal air temperature, rainfall, and minimal relative humidity with the examined traits (data not shown). However, we found a positive linear relationship $(P \leq 0.01)$ between average minimal monthly air temperature and leaf area infected (Fig. 1). These results suggest that farmers should be aware of disease progress if greater night temperatures are prevalent. However, more sensitive tests are necessary for a complete prognosis since infection development, beside other factors, depends on the interaction between temperature and leaf wetness (Sullivan et al., 2002). It seems that the use of a weather-based advisory program has potential to reduce the number of fungicide applications required to control white rust in spinach fields (Sullivan et al., 2003).

\section{Conclusions}

The scope of this study was to test spinach cultivars under highly favorable conditions for white rust and bolting. There were considerable differences among spinach cultivars in resistance to both white rust and bolting. Selection of white rust-resistant cultivars will enable more sustainable spinach production in areas where white rust historically has been the major fungal disease.

Slow-bolting spinach cultivars such as 'Fidalgo', 'Springfield', and 'Springer' appear suitable for areas with no white rust incidence and if they suit consumer market demands. Where spinach production is limited by white rust pressure, 'ASR-318', 'DMC 66-09', 'Fall Green', 'Samish', and 'San Juan' are suggested for large-scale production. However, 'DMC 66-09' and 'Samish' are bolting susceptible and should not be consider for plantings after late December.

\section{Literature cited}

Brandenberger, L., L.K. Wells, and M.M. Haigh. 2004. Yield and quality of spinach cultivars for spring production in Oklahoma. HortTechnology 14:602-605.

Correll, J.C., T.E. Morelock, M.C. Black, S.T Koike, L.P. Brandenberger, and F.J. Dainello. 1994. Economically important diseases of spinach. Plant Dis. 78:653-660.

Chun, C., A. Watanabe, H.H. Kim, and T. 
Table 5. Bolting rate of spinach cultivars in seasons 1998-2005 in southern Texas.

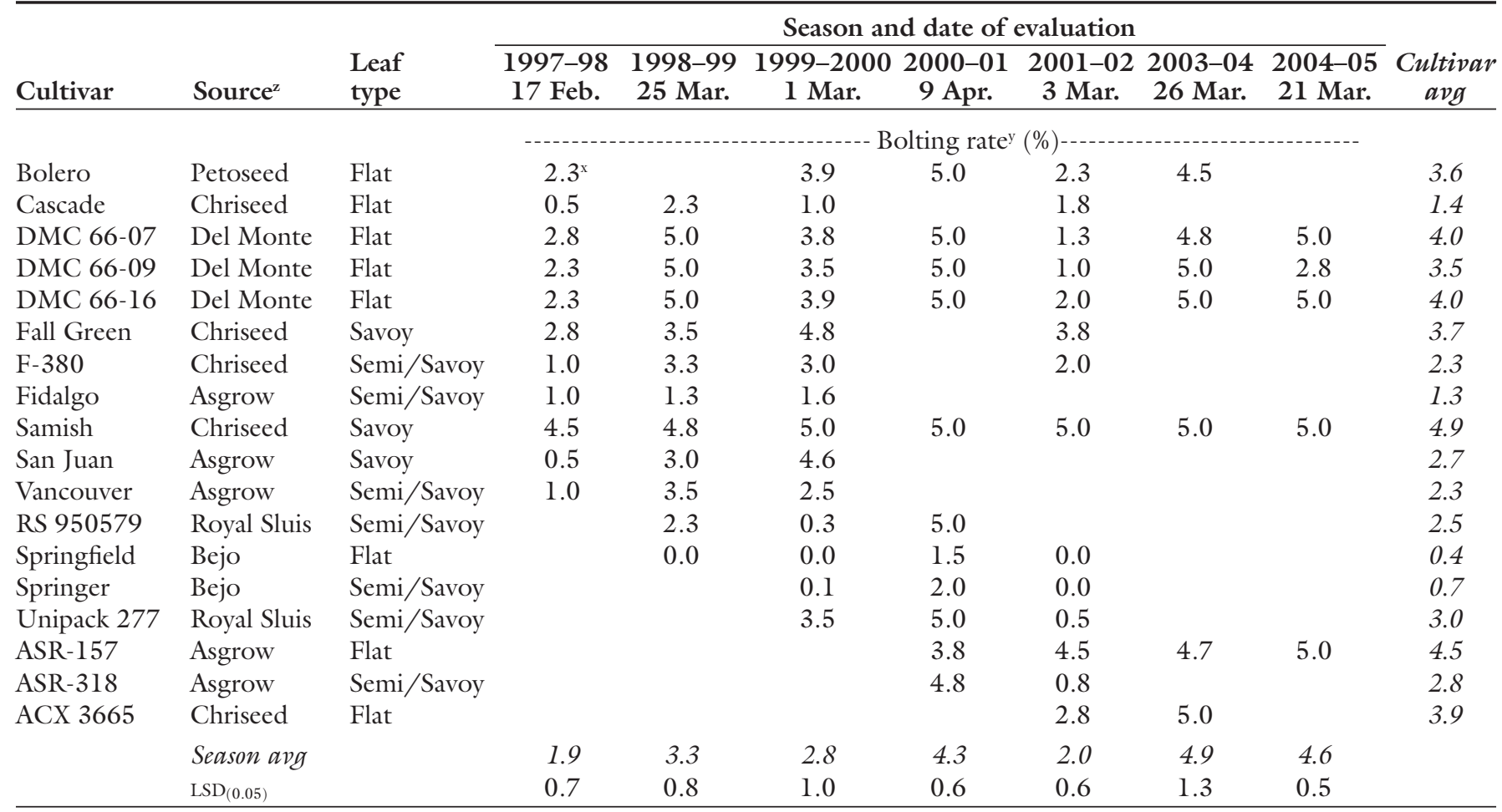

${ }^{2}$ Asgrow = Asgrow brand, Seminis Vegetable Seeds, Oxnard, Calif.; Bejo = Bejo Seeds, Oceano, Calif.; Chriseed = Chriseed brand, Alf Christianson Seed Co., Mount Vernon, Wash.; Del Monte $=$ Del Monte Corp., San Francisco; Petoseed $=$ Petoseed brand, Seminis Vegetable Seeds; Royal Sluis $=$ Royal Sluis brand, Seminis Vegetable Seeds. bolting rate was estimated as percentage of plants bolted per replication: $0=$ none; $1=1 \%$ to $20 \% ; 2=21 \%$ to $40 \%$; $3=41 \%$ to $60 \%$; $4=61 \%$ to $80 \%$; $5=81 \%$ to $100 \%$. Each value represents an average of four replications.

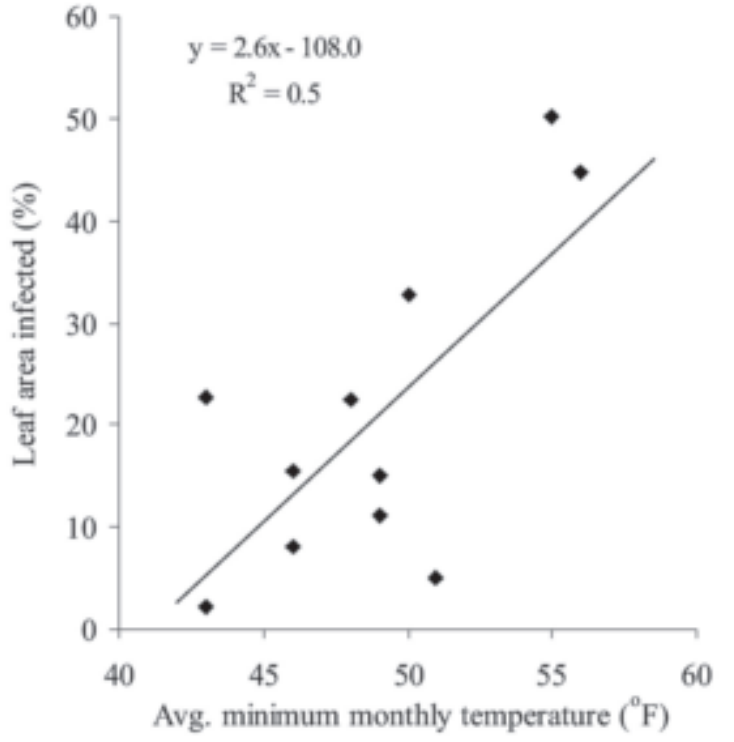

Fig. 1. Relationship between average minimal monthly air temperature $\left({ }^{\circ} \mathrm{F}\right)$ and leaf area infected with white rust of 18 spinach cultivars tested during 8 years. If the evaluation was done in the first $15 \mathrm{~d}$ of the month then data from the preceding month were used ( $\mathrm{Ta}$ bles 1 and 2). Each point represents an average leaf infected of all cultivars tested in that season ( 5 to 15); $\left({ }^{\circ} \mathrm{F}-32\right) / 1.8={ }^{\circ} \mathrm{C}$.
Kozai. 2000. Bolting and growth of Spinacea oleracea L. can be altered by modifying the photoperiod during transplant production. HortScience 35:624-626.

Dainello, F.J., M.C. Black, and T.E. Kunkel. 1990. Control of white rust of spinach with partial resistance and multiple soil applications of metalaxyl granules. Plant Dis. 74:913-916.

Goode, M.J., T.E. Morelock, and J.L. Bowers. 1987. Fall Green, a disease resistant spinach cultivar. Ark. Farm Res. 36:5.
Kim, H.H., C. Chun, T. Kozai, and J. Fuse. 2000. The potential use of photoperiod during transplant production under artificial lighting conditions on floral development and bolting, using spinach as a model. HortScience $35: 43-45$.

Leskovar, D.I. and M.C. Black. 1994. White rust infection and leaf chlorosis in relation to crop strategies in spinach. Environ. Expt. Bot. 34:363-370.

Leskovar, D.I. and K. Kolenda. 2002. Strobilurin + acibenzolar- $S$-methyl controls white rust without inducing leaf chlorosis in spinach. Ann. Appl. Biol. 140:171-175.

Magee, J.B. 1997. Some misconceptions about fruit and vegetables in human nutrition. Hort Technology 7:234-239.

Pena, J. 2004. The spinach harvest in Texas is winding down after a good season. $\mathrm{Ag}-\mathrm{EcO}$ News 20:9.

Raabe, R.D. and G.S. Pound. 1952. Relation of certain environmental factors to initiation and development of the white rust disease of spinach. Phytopathology 42:448-452.

Sullivan, M.J., J.P. Damicone, and M.E. Payton. 2002. The effects of temperature and wetness period on the development of spinach white rust. Plant Dis. 86:753-758.

Sullivan, M.J., J.P. Damicone, and M.E. Payton. 2003. Development of a weather-based advisory program for scheduling fungicide applications for control of white rust of spinach. Plant Dis. 87:923-928.

Texas Agricultural Statistics Service. 2003. Texas agricultural statistics. Texas Agr. Stat. Serv. Bul. 261.

Webb, R.E. and C.E. Thomas. 1976. Development of Fl spinach hybrids. HortScience 11:546. (Abstr.)

Wiebe, H.J. 1989. Effects of low temperature during seed development on the mother plant on subsequent bolting of chicory, lettuce and spinach. Scientia Hort. 38:223-229.

Yamaguchi, M. 1983. World vegetables. Principles, production and nutritive values. Avi Publ., Westport, Conn. 